\title{
Vaginal Vault Suspension at Hysterectomy for Prolapse - Myths and Facts, Anatomical Requirements, Fixation Techniques, Documentation and Cost Accounting
}

\author{
Scheidenstumpffixation im Rahmen der Prolaps-Hysterektomie - \\ Mythen und Fakten, anatomische Voraussetzungen, Fixationstechniken, Dokumentation und Abrechnung
}

Authors

Affiliations
F. Graefe ${ }^{1}$, J. Marschke ${ }^{1}$, T. Dimpfl' ${ }^{2}$, R. Tunn ${ }^{1}$

${ }^{1}$ Urogynäkologie, Deutsches Beckenbodenzentrum, Berlin

${ }^{2}$ Frauenheilkunde und Geburtshilfe, Klinikum Kassel, Kassel

\section{Key words}

- Vaginal vault suspension

- hysterectomy

- prolapse

- standard

Schlüsselwörter

- Scheidenstumpffixation

- Hysterektomie

- Prolaps

- Standard

\section{received $\quad 17.10 .2012$ \\ revised $\quad 12.11 .2012$ \\ accepted $\quad 14.11 .2012$}

Bibliography

DOI http://dx.doi.org/

10.1055/s-0032-1328061

Geburtsh Frauenheilk 2012; 72 :

1099-1106 @ Georg Thieme

Verlag KG Stuttgart · New York . ISSN 0016-5751

\section{Correspondence}

\section{Dr. Flora Graefe}

Deutsches Beckenbodenzentrum

Urogynäkologie

Große Hamburger Straße 5-11

10115 Berlin

r.tunn@alexius.de

\section{Abstract \\ $\nabla$}

Vaginal vault suspension during hysterectomy for prolapse is both a therapy for apical insufficiency and helps prevent recurrence. Numerous techniques exist, with different anatomical results and differing complications. The description of the different approaches together with a description of the vaginal vault suspension technique used at the Department for Urogynaecology at St. Hedwig Hospital could serve as a basis for reassessment and for recommendations by scientific associations regarding general standards.

\section{Myths and Facts}

Uterine prolapse can be treated by various conservative or operative measures. If the patient wishes operative correction with removal of the uterus, the gold standard is vaginal hysterectomy. The surgical steps are basically the same as those used for vaginal hysterectomies performed for other, benign, uterine pathologies. However, in hysterectomy procedures for prolapse, the focus is on treating the apical insufficiency and preventing prolapse of the vaginal stump, i.e. socalled vaginal vault suspension.

However, clinical practice has shown that in addition to attempting a topographically and physiologically correct suspension, techniques for additional fixation are used which entail anatomical compromises. And vaginal vault suspension is often not sufficiently taken into account. The selection of a specific approach is often not entirely based on scientific reasons. Usually the choice of approach is based on the surgical technique learned individually, the physician's own ideas and experiences, and techniques seen elsewhere. The authors do not exempt themselves.

\section{Zusammenfassung \\ $\nabla$}

Die Scheidenstumpffixation im Rahmen der Prolaps-Hysterektomie ist Therapie der apikalen Insuffizienz und gleichermaßen Rezidivprophylaxe. Es existieren zahlreiche Techniken, die mit unterschiedlichen anatomischen Resultaten und Komplikationen einhergehen. Die Darstellung der verschiedenen Vorgehensweisen und Vorstellung der Scheidenstumpffixationstechnik der Klinik für Urogynäkologie am St. Hedwig Krankenhaus kann als Grundlage für eine Neubewertung und Empfehlung durch die Fachgesellschaften zu einem einheitlichen Standard dienen.

\section{Mythen und Fakten}

Ein Descensus uteri kann durch verschiedene konservative und operative Maßnahmen behandelt werden. Wünscht die Patientin die operative Korrektur mit Entfernung des Uterus, ist hier die vaginale Hysterektomie der Goldstandard. Die operativen Schritte sind grundsätzlich die gleichen wie bei einer vaginalen Hysterektomie aufgrund anderer gutartiger Uteruspathologien. Jedoch liegt bei der Prolaps-Hysterektomie ein Schwerpunkt auf der Therapie der apikalen Insuffizienz und der Prophylaxe eines Scheidenstumpfdescensus, der sogenannten Scheidenstumpffixation.

Der klinische Alltag zeigt, dass, neben dem Bemühen topografisch-physiologisch korrekter Fixationen, Techniken für einen zusätzlichen Sicherungsbedarf Anwendung finden, die aber anatomische Kompromisse eingehen. Oder es wird der Scheidenstumpffixation kein relevanter Stellenwert zugesprochen. Die Gründe für das jeweilige Vorgehen sind nur bedingt wissenschaftlich basiert. Meistens ist es die gelernte Operationsschule, sind es eigene Ideen, Erfahrungen und woanders beobachtete Techniken, die zur Anwendung kommen. Die Autoren sehen sich hier gleichermaßen betroffen. 
A brief review of older and more recent literature throws up numerous different methods, although the literature does not always differentiate between prolapse and non-prolapse hysterectomy procedures, and illustrations of the operative site do not always correspond to the descriptions given.

We describe below a selection of the most well-known and important fixation techniques. Moschcowitz, who immigrated to the USA from Hungary at the end of the 19th century, published a report in 1912 on pouch of Douglas obliteration, primarily to treat "prolapse of the rectum" [1,2]. Halban, professor at the University of Vienna, described pouch of Douglas obliteration at surgery for vaginal prolapse [3]. Both techniques, originally described using an abdominal approach, were subsequently performed using a vaginal approach and for enterocele prophylaxis at hysterectomy. In 1957, McCall described a posterior culdoplasty performed at vaginal hysterectomy for enterocele correction [4]. His technique subsequently underwent numerous modifications, variously referred to as Mayo, Mayo-McCall or modified McCall culdoplasty [5-10]. Many variations of procedures for vaginal vault suspension using the uterosacral ligaments and a vaginal approach are similar to modifications of McCall culdoplasty procedures [11]. In 1968, Richter described vaginal sacrospinous fixation as a modification of sacrotuberal fixation (Amreich II), a procedure known since then in German-speaking countries as the "Amreich-Richter" procedure [8,12-14].

The above-mentioned procedures which use the patient's own tissue must be differentiated from abdominal operations and procedures using foreign material [15]. The latter include abdominal and laparoscopic colpo- and cervico-sacropexy procedures. The existing techniques for vaginal vault suspension have different postoperative anatomical results, complications and complication rates. At present, there is no consensus regarding a standardised procedure or guidelines for standardised procedures. The lack of a general standard affects patient satisfaction, health economics and even expert opinions in arbitration matters. The aim of this paper is to draw attention to this deficit and encourage a discussion of this topic by describing the technique used in the Department for Urogynaecology for vaginal vault suspension. One outcome of the discussion could be the creation of a basis for recommendations by scientific associations on standards for vaginal vault suspension done as part of hysterectomy procedures for prolapse.

\section{Anatomical Requirements for Vaginal Vault Suspension ( $\bullet$ Fig. 1)}

The key anatomical structures in vaginal vault suspension procedures are the uterosacral ligaments, the rotund ligaments and the retro-vesical and pre-rectal peritoneum. High peritonisation is done to reduce the pressure gradient between the abdomen and the vaginal apex. The former support structure of the uterus is used for apical fixation of the vaginal vault, with the uterosacral ligaments playing a key role. The parametria (cardinal ligaments) are also secured during transection of the uterine arteries but should not be included in vaginal vault fixation to prevent traction on them. None of the structures mentioned here is used as exclusive support. Histology and magnetic resonance imaging show loose connective tissue, with numerous vessels and nerves [16]. This is probably why uterine fixation procedures using individual tissue structures, for example, antefixation with reefing of

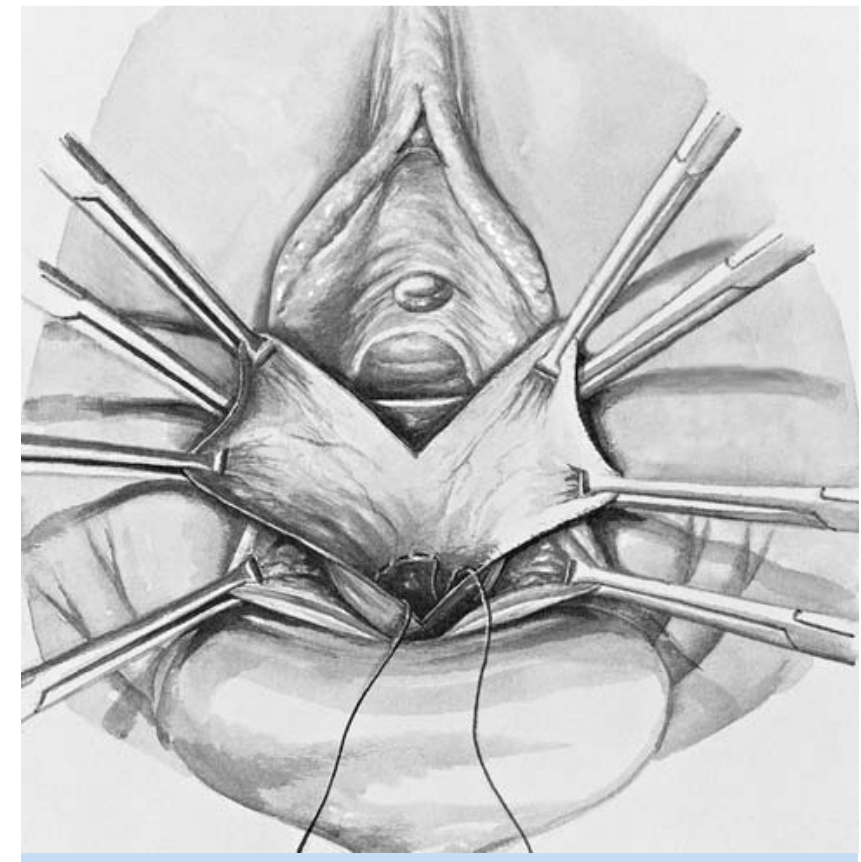

Fig. 1 High peritonisation, vaginal approach.

Schaut man in die ältere und aktuelle Literatur, findet sich eine Fülle verschiedener Methoden. Dabei wird nicht immer zwischen Prolapsund Nichtprolaps-Hysterektomie unterschieden, und Abbildungen zum Operationssitus stimmen nicht immer mit den dazugehörigen Beschreibungen überein.

Eine Auswahl der namhaften und wichtigsten Fixationstechniken wird im Folgenden beschrieben. Moschcowitz, der Ende des 19. Jahrhunderts aus Ungarn in die USA immigrierte, veröffentlichte 1912 eine Douglas-Obliteration, primär zur Behandlung des „Rektumprolapses“ [1,2]. Halban, Professor an der Universität Wien, stellte eine Douglas-Obliteration bei vaginalem Prolaps dar [3]. Beide Techniken, ursprünglich abdominal beschrieben, wurden in Folge auch vaginal und zur Enterozelenprophylaxe bei Hysterektomie durchgeführt. McCall beschrieb 1957 eine hintere Kuldoplastik zur Enterozelenkorrektur bei vaginaler Hysterektomie [4]. Seine Technik erfuhr zahlreiche Modifikationen, z. B. als Mayo-, Mayo-McCall- oder modifizierte McCall-Kuldoplastik bezeichnet [5-10]. Diesen Techniken ähnlich sind die Variationen der vaginalen Scheidenstumpfsuspension an den Ligg. sacrouterina [11]. Richter beschrieb 1968 die vaginale sakrospinale Fixation als Modifizierung der sakrotuberalen Fixation (Amreich II), die seitdem im deutschsprachigen Raum als „AmreichRichter"-Operation bekannt ist [8,12-14].

Von den bisher genannten mit körpereigenem Gewebe durchgeführten Methoden sind die abdominalen und unter Einsatz von Fremdmaterial erfolgenden Operationen abzugrenzen [15]. Hierzu gehören die offen abdominale bzw. laparoskopische Kolpo- und Zervikosakropexie.

Die existierenden Techniken zur Scheidenstumpffixation gehen mit unterschiedlichen postoperativen anatomischen Resultaten, Komplikationen und Komplikationshäufigkeiten einher. Es besteht kein Konsens zu einem standardisierten Vorgehen, das in Leitlinien festgesetzt ist. Der fehlende Standard hat wiederum Einfluss auf die Patientenzufriedenheit, gesundheitsökonomische Aspekte und schließlich die gutachterliche Einschätzung bei Schlichtungsfragen. Ziel der vorliegenden Arbeit ist es, auf diesen Missstand aufmerksam zu machen und durch das Vorstellen der in der Klinik für Urogynäkologie durch- 


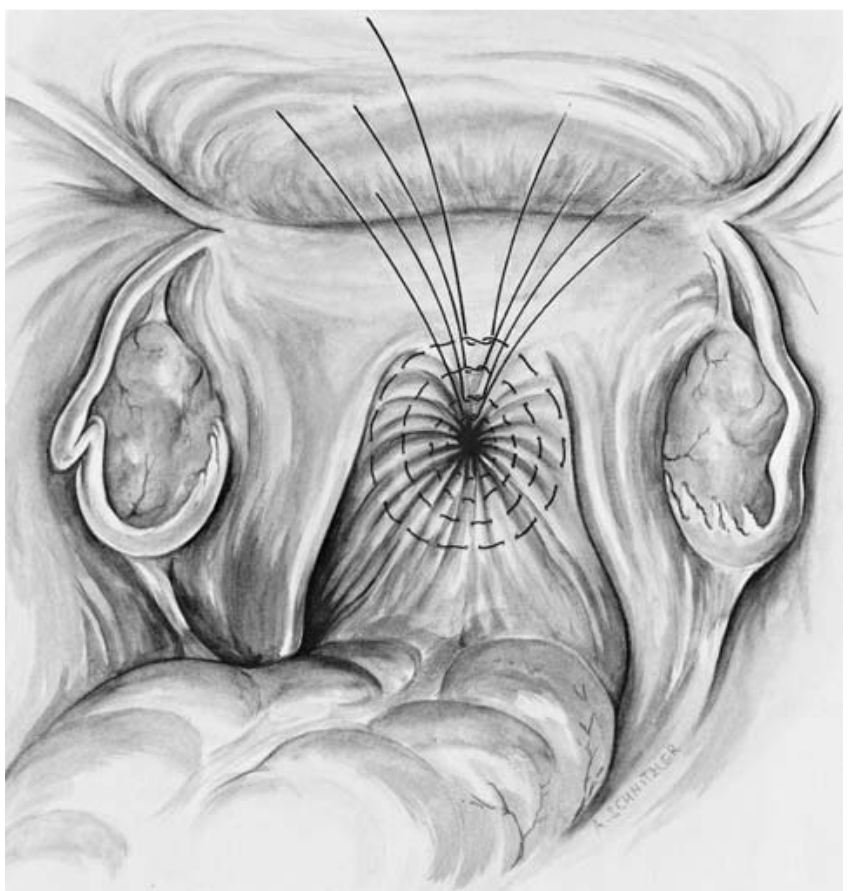

Fig. 2 Moschcowitz obliteration of the pouch of Douglas, abdominal approach.

the rotund ligaments or hysteropexy with plication of the uterosacral ligaments, have not prevailed in clinical practice.

\section{Well-known Fixation Techniques - Clinical and Scientific Facts}

Moschcowitz procedure with pouch

of Douglas obliteration ( $\odot$ Fig. 2 )

The peritoneum is included using $6-8$ purse-string sutures until the entire pouch of Douglas is obliterated [2].

Cruikshank and Kovac compare a modified form of the procedure with simple high peritonisation and a modified McCall culdoplasty. After 3 years, 6 of 33 cases had developed grade 2 enterocele (Pelvic Organ Prolapse Quantification, POPQ). As most cases had not developed prolapse preoperatively, these results are of only limited significance. No complications associated with the closure technique are reported [6].

\section{Halban procedure with pouch of Douglas obliteration}

The peritoneum is closed with sagittal sutures [3].

The authors could not find any scientific studies of this technique.

\section{McCall's posterior culdoplasty}

Three "internal sutures" are placed from one uterosacral ligament to the other, and the cul-de-sac peritoneum is included several times in between. The "internal sutures" are initially not tightened. Three "external sutures" are then placed. The external suture is placed from the vaginal side into the peritoneal cavity at $2 \mathrm{~cm}$ left of the 6 o'clock position. The left and right uterosacral ligaments are then taken. Last the external suture is placed from the peritoneal to the vaginal side at $2 \mathrm{~cm}$ right of the 6 o'clock position. The "internal sutures" are tied before the "external su- geführten Scheidenstumpffixationstechnik eine Diskussion dieser Thematik anzuregen. Im Ergebnis der Diskussion könnte die Grundlage einer Empfehlung für einen Standard zur vaginalen Scheidenstumpffixation im Rahmen der Prolaps-Hysterektomie durch die Fachgesellschaft geschaffen werden.

\section{Anatomische Voraussetzungen für die Scheidenstumpffixation ( $\odot$ Abb. 1)}

$\nabla$

Die wesentlichen anatomischen Leitstrukturen bei der Scheidenstumpffixation sind die Ligg. sacrouterina, die Ligg. rotunda sowie das retrovesikale und prärektale Peritoneum. Eine hohe Peritonealisierung wird durchgeführt, um die Weiterleitung der Druckbelastung aus dem Bauchraum auf den Scheidenapex zu vermindern. Der ehemalige Halteapparat des Uterus dient der apikalen Fixation des Scheidenstumpfs. Den Ligg. sacrouterina wird dabei die maßgebliche Haltefunktion zugesprochen. Die Parametrien (Ligg. cardinalia) werden beim Absetzen der Aa. uterinae mitgegriffen, sollten in die Scheidenstumpffixation jedoch nicht einbezogen werden, um sie keiner Zugbelastung auszusetzen. Jede einzelne der genannten Strukturen kommt keiner ausschließlichen Haltefunktion nach. Histologische und kernspintomografische Untersuchungen spiegeln eher lockeres Bindegewebe mit reichlich Gefäßen und Nerven wider [16]. Daraus resultiert sicher auch, dass Uterusfixationsoperationen unter Nutzung einzelner Gewebestrukturen, wie z.B. die Antefixationsoperation durch Raffung der Ligg. rotunda oder die Hysteropexie durch Raffung der Ligg. sacrouterina, sich im klinischen Alltag nicht behauptet haben.

\section{Bekannte Fixationstechniken - klinische und wissenschaftliche Fakten \\ $\nabla$}

Douglas-Obliteration nach Moschcowitz ( $\bullet$ Abb. 2)

Mit 6-8 zirkulären Nähten wird das Peritoneum aufgegriffen, bis der gesamte Douglas-Raum verstrichen ist [2].

Cruikshank und Kovac vergleichen eine modifizierte Form mit einer einfachen hohen Peritonealisierung und einer modifizierten McCallKuldoplastik. Nach 3 Jahren traten in 6 von 33 Fällen Enterozelen 2. Grades (Pelvic Organ Prolapse Quantification, POPQ) auf. Da in den meisten Fällen präoperativ kein Prolaps vorlag, sind die Ergebnisse nur bedingt aussagekräftig. Es werden keine Komplikationen beschrieben, die sich mit der Verschlusstechnik in Zusammenhang bringen lassen [6].

\section{Douglas-Obliteration nach Halban}

Der Verschluss des Peritoneums erfolgt mit sagittalen Nähten [3]. Wissenschaftliche Untersuchungen zu dieser Technik wurden von den Autoren nicht gefunden.

\section{Hintere Kuldoplastik nach McCall}

Zunächst werden 3 „innere Nähte“ von einem Lig. sacrouterinum zum anderen gesetzt. Dazwischen wird das Douglas-Peritoneum mehrmals aufgegriffen. Die „inneren Nähte“ werden vorerst nicht zugezogen. Es folgen 3 „äußere Nähte“. Von der vaginalen Seite $2 \mathrm{~cm}$ links der 6-Uhr-Mittellinie wird die äußere Naht in den peritonealen Raum gelegt. Dann erfolgt das Aufgreifen des linken und rechten Lig. sacrouterinum. Der Anschluss wird mit Durchstechen zur vaginalen Seite $2 \mathrm{~cm}$ rechts der 6-Uhr-Mittellinie gefunden. Die ,inneren“ werden vor den „äußeren Nähten“ geknüpft [6]. Cruikshank und Kovac beschreiben eine modifizierte McCall-Kuldoplastik, bei der nur eine 
tures" [6]. Cruikshank and Kovac describe a modified McCall culdoplasty which uses only one purse-string suture, starting at the 12 o'clock position in the peritoneal cavity. The cardinal ligament and uterosacral ligament on one side are taken. Shortly before reaching the 6 o'clock position, the suture is placed vaginally and then, after $2 \mathrm{~cm}$, placed in the peritoneal cavity again. The ligaments on the other side are then attached [4].

Ureteral injury is reported as a typical complication of McCall's culdoplasty technique. However, this complication is only reported in one of the 5 investigated studies of the vaginal McCall technique and definitely occurred only in 1 of 211 cases [6-10]. Colombo and Milani compare a modified McCall culdoplasty with sacrospinous fixation done during hysterectomy for prolapse in two groups of 62 patients with a follow-up of 5 years. In the group treated with the McCall procedure, blood loss did not exceed $500 \mathrm{ml}$. Prolapse of the apical, anterior, or posterior compartments up to the introitus or beyond occurred postoperatively in $5 \%$ of patients in this group. Around $5 \%$ of patients discontinued sexual activity because of dyspareunia [8]. Chene et al. describe the results of a study in 185 patients with a follow-up of 2 years. A modified form of the McCall culdoplasty was carried out during hysterectomy for prolapse. In $1.1 \%$ of cases, blood loss was higher than $500 \mathrm{ml}$. At 2 years after operation, $89.2 \%$ of cases had no and $10 \%$ had developed grade 1 vaginal vault prolapse (POPQ). Grade 1 or 2 secondary cystocele developed in 3\% and grade 1 or 2 secondary rectocele in $4.5 \%$ of cases. In the group of 85 sexually active women, one subsequently suffered permanent dyspareunia [9].

\section{Uterosacral ligament vaginal vault suspension using a vaginal approach}

Shull et al. describe this technique in a study of 289 patients, 85 of whom underwent simultaneous vaginal hysterectomy. In the remaining cases the procedure was done to treat vaginal vault prolapse after hysterectomy. In this technique, the uterosacral ligament is taken sacrally to the ischial spine with a double-armed suture. Two more sutures are placed in the uterosacral ligament towards the sacrum. The contralateral ligament is sutured the same way. Then the pubocervical fascia is included laterally to the vaginal vault using the upper arm of the first suture. Sutures 2 and 3 are placed medially in the pubocervical fascia. The rectovaginal fascia of the vaginal vault is sutured using the lower sutures. The contralateral fascias are sutured in the same way. The sutures are then tied.

In the study cited above, 3 patients required a blood transfusion. There were 2 ureteral injuries found on cystoscopy during operation and subsequently rectified. Three of 289 patients developed grade 2 or 3 apical recurrence (Baden-Walker classification). Ten cases developed cystocele and 4 cases developed rectocele grade 2 or 3 . No difference was found between the procedures carried out with and without hysterectomy [11].

\section{Amreich-Richter technique of sacrospinous fixation}

After a posterior colpotomy, the rectal stalk is bluntly penetrated and prepared up to the ischial spine. The sacrospinous ligament is exposed and 2-3 sutures are placed. The vaginal vault is included subepithelially and the sutures are tied on the sacrospinous ligament [12].

A number of studies in which sacrospinous fixation was done during hysterectomy for prolapse report the subsequent development of cystocele. Colombo and Milani describe the development of grade 2 and higher cystocele in $21 \%$ of patients at fol- zirkuläre Naht gesetzt wird. Sie beginnt bei $12 \mathrm{Uhr}$ im peritonealen Raum. Lig. cardinale und Lig. sacrouterinum einer Seite werden gefasst. Kurz vor 6 Uhr wird die Naht zur vaginalen Seite und nach $2 \mathrm{~cm}$ wieder in den peritonealen Raum gelegt. Die Ligamente der anderen Seite werden gefasst und der Anschluss gefunden [4].

Als typische Komplikation der McCall-Kuldoplastik wird das Umstechen der Ureteren genannt. Allerdings findet sich diese Komplikation in nur einer der 5 untersuchten Studien zur vaginalen McCall-Technik und trat dort sicher in nur 1 von 211 Fällen auf [6-10]. Colombo und Milani vergleichen eine modifizierte McCall-Kuldoplastik mit einer sakrospinalen Fixation im Rahmen der Prolaps-Hysterektomie bei je 62 Patienten in einem 5-Jahres-Follow-up. Bei der Gruppe der McCallTechnik wird kein Blutverlust über $500 \mathrm{ml}$ beschrieben. Ein Prolaps des apikalen, vorderen oder hinteren Kompartiments bis zum Introitus oder weiter trat postoperativ mit jeweils $5 \%$ in dieser Gruppe auf. Sexuelle Aktivität wurde bei $5 \%$ der Patienten wegen Dyspareunie eingestellt [8]. Chene et al. beschreiben die Ergebnisse einer Studie mit 185 Patienten und einem 2-Jahres-Follow-up. Die McCall-Kuldoplastik wurde im Rahmen der Prolaps-Hysterektomie in einer modifizierten Form durchgeführt. In 1,1\% kam es zu einem Blutverlust von über $500 \mathrm{ml}$. Nach 2 Jahren stellte sich in $89,2 \%$ kein und in $10 \%$ ein Scheidenstumpfdescensus 1. Grades (POPQ) dar. Eine sekundäre Zystozele trat bei $3 \%$ und eine sekundäre Rektozele bei 4,5\% mit jeweils Grad 1 oder 2 auf. Von 85 sexuell aktiven Frauen litt eine unter bleibender Dyspareunie [9].

\section{Vaginale Scheidenstumpfsuspension} an den Ligg. sacrouterina

Shull et al. beschreiben diese Technik in einer Studie mit 289 Patienten, von denen 85 gleichzeitig eine vaginale Hysterektomie erhielten. Bei den restlichen Fällen wurde der Eingriff aufgrund eines Scheidenstumpfdescensus nach Hysterektomie durchgeführt. Dabei wird ein Lig. sacrouterinum auf der sakralen Seite der Spina ischiadica mit einem doppelt armierten Faden durchstochen. Zwei weitere Fäden werden in das Lig. sacrouterinum Richtung Os sacrum gelegt. Mit dem gegenüberliegenden Ligament wird in gleicher Weise verfahren. Danach wird die pubozervikale Faszie am lateralen Scheidenende mit der oberen Nadel der zuerst gesetzten Naht erfasst. Medial davon werden die Fäden 2 und 3 in die pubozervikale Faszie gelegt. In gleicher Weise wird die rektovaginale Faszie des Scheidenendes mit den unteren Nadeln ergriffen. Ebenso werden die gegenüberliegenden Faszien eingebunden. Zum Schluss werden die zusammengehörenden Fadenenden geknüpft.

In der oben genannten Studie erhielten 3 Patienten eine Bluttransfusion, und es kam zu 2 Ureterumstechungen, die während des Eingriffs zystoskopisch entdeckt wurden und revidiert werden konnten. Ein apikales Rezidiv 2. oder 3. Grades (Klassifikation nach Baden-Walker) erlitten 3 von 289 Patienten. In 10 Fällen trat eine Zystozele und in 4 Fällen eine Rektozele 2. oder 3. Grades auf. Dabei konnte kein Unterschied zwischen den Eingriffen mit oder ohne Hysterektomie ausgemacht werden [11].

\section{Sakrospinale Fixation nach Amreich und Richter}

Nach hinterer Kolpotomie wird der Rektumpfeiler stumpf durchstoßen und bis zur Spina ischiadica präpariert. Nach Freilegung des Lig. sacrospinale werden dort 2-3 Nähte gelegt. Das Scheidenende wird subepithelial durchstochen und die Fäden auf das Lig. sacrospinale geknüpft [12].

Verschiedene Studien, bei denen die sakrospinale Fixation im Rahmen der Prolaps-Hysterektomie durchgeführt wurde, weisen die nachfolgende Zystozele als große Gemeinsamkeit auf. Colombo und Milani beschreiben eine Zystozele ab Grad 2 bei $21 \%$ im 5-Jahres-Fol- 
low-up after 5 years [8], Maher et al. report grade 1 and above cystocele development (modified Baden-Walker classification) in $28 \%$ of patients after an average follow-up of 3 years [13], and Lopes et al. report $44 \%$ patients with grade 3 or 4 cystocele (POPQ) at 1-year follow-up [14]. In the study by Colombo and Milani, $16 \%$ of patients had blood loss of more than $500 \mathrm{ml}$ and $5 \%$ of patients required blood transfusion. $8.5 \%$ of cases discontinued sexual activity because of dyspareunia. Maher et al. report dyspareunia in $3 \%$ of sexually active patients.

\section{Open abdominal and laparoscopic \\ colpo- and cervico-sacropexy}

After total or subtotal hysterectomy, the posterior and anterior vaginal walls are prepared depending on whether cystocele or rectocele is present. A mesh is sutured on either side. In cervicosacropexy procedures, an individual mesh may also be attached posterior to the cervix. The proximal ends of the mesh are fixed to the sacrum or, particularly in laparoscopic procedures, to the sacral promontory. Sutures or titanium screws are used. The mesh is then peritonealised.

Bensinger et al. report on a study with 121 patients divided into 3 groups for comparison. Group 1 underwent supracervical hysterectomy with colposacropexy, Group 2 underwent total abdominal hysterectomy with colposacropexy, and Group 3 only underwent colposacropexy after previous hysterectomy. A macroporous monofilament polypropelene mesh was used. While there was no mesh erosion in Groups 1 and 3, mesh erosion occurred in $8.2 \%$ of patients with total hysterectomy. Additional complications with an incidence of between 2.5 and $4.7 \%$ included injuries to the small bowel and the bladder, ileus and persistent vaginal discharge. $1.7 \%$ of patients required blood transfusion. Dyspareunia occurred in $6.7 \%$ of cases, and $2.5 \%$ of cases had prolapse recurrence (POPQ). The percentages were equally distributed between groups [15].

\section{Suspension Technique Used in the Department for Urogynaecology \\ $\nabla$}

The suspension technique described here was first developed at the Gynaecological Department of the Charité, Humboldt University of Berlin. Developed by Walter Stoeckel, continued by Helmut Kraatz and Wolfgang Fischer and adapted to take advantage of the most recent suture materials, this technique was implemented in general clinical practice at the Department for Urogynaecology of St. Hedwig Hospital in 2009. The modifications were done primarily with the aim of leaving less suture material in situ, causing less injury to tissue and to create a suspension which more closely resembles the female physiology. The basic principles of the original technique were retained.

The needle is initially left in place at the end of the ligature of the uterosacral ligaments and adnexa with the rotund ligaments. To carry out vaginal vault suspension using a vaginal approach, the herniated bowel is repositioned out of the rectouterine pouch. The bladder peritoneum is mobilised and taken approximately $2 \mathrm{~cm}$ above the level of the incision site, the pre-rectal peritoneum is mobilised and taken at the start of the pre-rectal adipose tissue, the rotund ligaments and the uterosacral ligaments are included separately. The peritoneum is closed using purse-string sutures as defined by high peritonisation with including the mentioned structures; the peritoneum at the pelvic wall is only included vapidly to prevent ligature of the ureters. The cul-de- low-up [8], Maher et al. bei 28\% ab Grad 1 (modifizierte Klassifikation nach Baden-Walker) in einem durchschnittlichen 3-Jahres-Follow-up [13] und Lopes et al. bei $44 \%$ mit Grad 3 oder 4 (POPQ) im 1-JahresFollow-up [14]. Bei Colombo und Milani trat des Weiteren in 16\% der Fälle ein Blutverlust über $500 \mathrm{ml}$ auf und $5 \%$ der Patienten mussten transfundiert werden. In 8,5\% der Fälle wurde sexuelle Aktivität wegen Dyspareunie eingestellt. Maher et al. nennen Dyspareunie bei 3\% der sexuell Aktiven.

\section{Offen abdominale und laparoskopische \\ Kolpo- und Zervikosakropexie}

Nach totaler oder subtotaler Hysterektomie werden die hintere und vordere Scheidenwand in Abhängigkeit von einer gleichzeitig bestehenden Zystozele oder Rektozele präpariert. Je ein Netz wird dort angenäht. Bei der Zervikosakropexie ist auch die Befestigung eines einzelnen Netzes hinten an der Zervix möglich. Die proximalen Netzenden werden am Os sacrum oder insbesondere bei der laparoskopischen Technik am Promontorium fixiert. Hierbei kommen Nähte oder Titaniumschrauben zum Einsatz. Abschließend können die Netze peritonealisiert werden.

Bensinger et al. beschreiben eine Studie mit 121 Patienten, in der 3 Gruppen miteinander verglichen werden. Gruppe 1 erhielt eine suprazervikale Hysterektomie und Kolposakropexie, Gruppe 2 eine totale abdominale Hysterektomie und Kolposakropexie und Gruppe 3 nur eine Kolposakropexie bei bereits stattgehabter Hysterektomie. Es wurde ein makroporöses monofilamentäres Polypropylennetz verwendet. Während in Gruppe 1 und 3 keine Netzerosion auftrat, war dies bei $8,2 \%$ der Patienten mit totaler Hysterektomie der Fall. Weitere Komplikationen mit 2,5 bis 4,7\% waren Dünndarm- und Blasenläsionen, Ileus und persistierender vaginaler Ausfluss. Bluttransfusionen fanden in 1,7\% statt. Dyspareunie trat in 6,7\% und ein Rezidivprolaps (POPQ) in 2,5\% der Fälle auf. Diese Prozentzahlen waren auf die Gruppen gleich verteilt [15].

\section{Fixationstechnik der Klinik für Urogynäkologie}

\section{$\nabla$}

Die im Folgenden beschriebene Fixationstechnik hat ihren Ursprung an der Frauenklinik der Charité, Humboldt Universität zu Berlin. Von Walter Stoeckel geprägt, Helmut Kraatz und Wolfgang Fischer fortgeführt und den jeweils aktuellen Nahtmaterialien angepasst, hat sie an der Klinik für Urogynäkologie des St. Hedwig Krankenhauses im Jahr 2009 die beschriebene Umsetzung erfahren. Die durchgeführten Modifikationen erfolgten vordergründig, um weniger Nahtmaterial im Situs zu belassen, weniger Gewebe zu traumatisieren und noch physiologischer zu fixieren. Die Grundsätze der ursprünglichen Technik wurden bewahrt.

Die Fadenenden der Ligatur der Ligg. sacrouterina und Adnexe mit Ligg. rotunda werden mit Nadeln belassen. Zur Durchführung der vaginalen Scheidenstumpffixation werden die Darmanteile aus dem Douglas'schen Raum reponiert. Mobilisiert und gefasst werden das Blasenperitoneum ca. $2 \mathrm{~cm}$ oberhalb der Absetzungsebene, das prärektale Peritoneum in Höhe des Beginns des prärektalen Fettgewebes, die Ligg. rotunda und die Ligg. sacrouterina separat. Mittels zirkulärer Naht wird das Peritoneum im Sinne einer hohen Peritonealisierung durch Mitfassen der genannten Strukturen verschlossen, wobei bds. an der Beckenwand das Peritoneum nur flach gefasst wird, um eine Ureterligatur zu verhindern. Damit obliteriert der Douglas'sche Raum durch Adaption des Blasen- und Rektumperitoneums. Überschüssiges Peritoneum wird an die anteriore Fascia endopelvina zur Stabilisierung des anterioren Scheidenapex adaptiert. Nun werden die Scheidenecken in Höhe des Parakolpiums angezügelt und un- 
sac pouch is obliterated through adaptation of the bladder peritoneum and rectal peritoneum. Excess peritoneum is adapted to the anterior endopelvic fascia to stabilise the anterior vaginal apex. The vaginal corners are taken at the level of the paracolpium and the previously shortened rotund and uterosacral ligaments are sutured to the vaginal corners using the sutures mentioned above. This repositions the base of the vagina up to the level of the middle third of the vagina. It also acts as a tamponade for vascular stumps and parametria, preventing secondary bleeding and extensive haematoma formation.

The authors are of the opinion that high peritonisation using purse-string sutures including all mentioned structures and suturing of the uterosacral and rotund ligaments to the base of the vagina results in the even distribution of abdominal pressure and symmetrical suspension of the vaginal vault. This procedure provides both therapy and prevention.

\section{Documentation and Cost Accounting}

$\nabla$

Vaginal vault suspension using a vaginal approach represents a separate operative procedure ("vaginal vault fixation, vaginal approach") used to rectify inadequate suspension of the vaginal apex (level 1 [17]). The OPS code is 5-704.43. The DRG code is N04Z with a weight of 1.475 when vaginal hysterectomy is coded together with vaginal vault suspension. Additional cysto- or rectocele correction does not change the DRG or the weight.

\section{Discussion}

\section{$\nabla$}

Clinical routine and scientific data show that hysterectomy procedures for prolapse combined with cysto- or rectocele correction may be the "gold standard" in the primary operative therapy of uterovaginal prolapse, but there appears to be no consistent standard in terms of perception, surgical implementation or prospect of success.

The studies mentioned are only a few examples, but they represent the typical anatomical outcomes and complications associated with the different procedures. Many physicians do not place enough confidence in modified McCall techniques for vaginal vault suspension, even though the limited scientific data attests to the good anatomical outcomes and low rates of complications. One reason for this could be the numerous types of procedures described.

If high reefing of the uterosacral ligaments (e.g. using the technique of Shull et al. [11]) is done, routine cystoscopic control of ureter function is mandatory, making this procedure less suitable for routine clinical practice or standardisation.

Sacrospinous fixation in a hysterectomy procedure, usually done on the right side in accordance with the technique of Amreich and Richter, plays a not unimportant role in clinical practice. However, the high rate of cystocele recurrence due to changes of the vaginal axis towards the sacrum, the perioperative complications and the dyspareunia rate calls for a reassessment of this procedure. The additional vaginal approach to reach the sacrospinous ligament makes this a more invasive procedure.

Posterior intravaginal slingplasty has largely been replaced by the use of transischioanal and transvaginal meshes for the posterior compartment, as use of the multifilament material is associated with high rates of infection, and broader stabilisation proved to have more advantages compared to band fixation alone. To- ter Verwendung der obengenannten Fäden die vorher gekürzten Ligg. rotunda et sacrouterina in die Scheidenecken eingenäht. Dabei reponiert sich der Scheidengrund bis zur Höhe des mittleren Vaginaldrittels. Gleichermaßen werden dadurch die Gefäßstümpfe und Parametrien tamponiert, um eine Nachblutung bzw. Hämatomausbreitung zu verhindern.

Die hohe Peritonealisierung durch zirkuläre Einbeziehung aller genannten Strukturen sowie das Einnähen der Ligg. sacrouterina und Ligg. rotunda in den Scheidengrund führt nach Vorstellung der Autoren zur Gleichverteilung des abdominalen Druckes und symmetrischen Fixation des Scheidenstumpfes. Dies hat gleichermaßen therapeutischen und präventiven Charakter.

\section{Dokumentation und Abrechnung \\ $\nabla$}

Die vaginale Scheidenstumpffixation stellt eine eigene operative Prozedur („vaginale Scheidenstumpffixation, vaginaler Zugang“) zur Behebung der Insuffizienz der apikalen Fixation der Vagina (Level 1 [17]) dar. Sie wird mit der OPS-Ziffer 5-704.43 verschlüsselt. Daraus resultiert die DRG N04Z mit einem Kostengewicht von 1,475, wenn die vaginale Hysterektomie mit der Scheidenstumpffixation zusammen verschlüsselt wird. Die zusätzliche Zysto- oder Rektozelenkorrektur führt zu keiner Änderung der DRG bzw. des Kostengewichts.

\section{Diskussion \\ $\nabla$}

Klinischer Alltag und wissenschaftliche Daten zeigen, dass die Prolaps-Hysterektomie in Kombination mit der Zelenkorrektur zwar den „Goldstandard“ in der primären operativen Therapie des Uterovaginalprolapses darstellt, aber weder in der Wahrnehmung, operativen Umsetzung noch den Erfolgsaussichten ein einheitlicher Standard erkennbar ist.

Die oben genannten Studien können nur als beispielhaft gelten, repräsentieren jedoch typische anatomische Resultate und Komplikationen der verschiedenen Vorgehensweisen. Zur Realisierung der Scheidenstumpffixation wird den Techniken nach McCall vielerorts nicht genügend Vertrauen geschenkt, obwohl die wenigen wissenschaftlichen Daten gute anatomische Ergebnisse und ein geringes Komplikationsrisiko bescheinigen. Schuld daran kann auch die Vielzahl der beschriebenen Vorgehensweisen sein.

Bei einer hohen Raffung der Ligg. sacrouterina (z. B. nach Shull et al. [11]) erscheint die routinemäßige zystoskopische Kontrolle der Ureterenfunktion obligat, ist dadurch für den klinischen Alltag bzw. eine Standardisierung aber eher ungeeignet.

Die sakrospinale Fixation im Rahmen der Hysterektomie, meistens rechtsseitig nach Amreich und Richter durchgeführt, scheint im klinischen Alltag einen relevanten Stellenwert zu haben, obwohl die hohe Rate an Rezidiv-Zystozelen durch die Sakralisierung der Vaginalachse, die perioperativen Komplikationen und die DyspareunieRate eine Neubewertung dieses Vorgehens förmlich verlangen. Der zusätzliche vaginale Zugang, um an das Lig. sacrospinale zu gelangen, stellt eine erhöhte Invasivität dar.

Die posteriore intravaginale Schlingenplastik wurde weitestgehend von den transischioanalen und transvaginalen Netzen für das hintere Kompartiment abgelöst, da das multifilamentäre Material hohe Infektionsraten verursacht und eine flächenhafte Stabilisierung Vorteile gegenüber der alleinigen Bandfixation gezeigt hat. Komplett transvaginal applizierte Netze als auch transobturatorische Netze mit Sechs-Punkt-Fixation dienen ebenfalls der Stabilisierung des Scheidenapex. Hauptsächlich werden sie jedoch zur Unterstützung des 
tally transvaginal meshes and transobturator meshes with sixpoint fixation are also used to stabilise the vaginal vault. However, they are mainly used to support the posterior and anterior compartment, and above all to correct prolapse recurrence. The so-called total meshes used with concomitant hysterectomy procedures have been found to have erosion rates of up to $14.4 \%$ in the scar tissue of the vaginal vault [18].

The technique described above used in the Department for Urogynaecology for vaginal vault suspension in hysterectomy procedures for prolapse with cele correction using a vaginal approach has been used without exception in our Department since 2009 and is used to treat uterine prolapse of all degrees of severity. In the period from 2009 to 2011, a total of 517 women were operated and the perioperative results up until 8 weeks postoperatively were assessed. There were no haematomas requiring revision in the scar tissue of the vaginal vault, no injuries to the bladder or rectum, and no ureteral injuries requiring revision. No patient required blood transfusion. At the first follow-up examination (6-8 weeks postoperatively) there was no recurrence requiring surgical revision, and no patient required pessary therapy. But medium-term data on the incidence of prolapse recurrence will be necessary to make a conclusive evaluation. The authors consider that the limited invasiveness, standardised anatomical structures used, minimal use of material and the preservation of the physiological vaginal axis are all important advantages of this procedure compared to other methods. Based on these experiences, the Amreich-Richter procedure for sacrospinous fixation in hysterectomy for prolapse is no longer done in the Department for Urogynaecology.

Abdominal (open or laparoscopic) hysterectomy for prolapse appears to play a secondary role in clinical practice. It is more expensive compared to the vaginal approach and has the additional disadvantage of a higher incidence of mesh erosion at the base of the vagina, although the anatomical outcomes are excellent. Cervicopexy during supracervical hysterectomy has similar anatomical results as colpopexy, but fistula formation of the cervical canal can occur with this technique.

\section{Conclusion}

Hysterectomy for prolapse needs to be combined with vaginal vault suspension as part of vaginal reconstruction after prolapse. Basically three different methods are currently used: a vaginal approach including the shortened ligamentous structures of the uterus; an additional vaginal approach with fixation at the sacrospinous ligament; and cervico-/colposacropexy with mesh interposition as part of abdominal or laparoscopic total or supracervical hysterectomy. All 3 methods represent separate procedures in addition to the actual hysterectomy procedure. They require an independent risk assessment and should therefore be part of the preoperative discussion with patients. This, in turn, justifies their separate assessment in the DRG system. Recommendations by scientific associations could contribute to ensuring a more standardised procedure. The suspension technique used at the Department for Urogynaecology described here offers a good basis for discussion. vorderen und hinteren Kompartiments eingesetzt und dienen vorrangig der Korrektur des Rezidivprolapses. Die sogenannten totalen Netze imponierten bei gleichzeitiger Hysterektomie durch Netzerosionsraten bis zu 14,4\% im Bereich der Scheidenabschlussnarbe [18]. Die in der Klinik für Urogynäkologie angewandte, oben beschriebene Technik zur Scheidenstumpffixation im Rahmen der vaginalen Prolaps-Hysterektomie mit Zelenkorrektur wird seit 2009 einheitlich und bei allen Graden eines Descensus uteri durchgeführt. Im Zeitraum von 2009 bis 2011 wurden 517 Frauen operiert und die perioperativen Ergebnisse bis 8 Wochen postoperativ ausgewertet. Es traten keine revisionspflichtigen Hämatome im Bereich der Scheidenabschlussnarbe, Harnblasen-, Rektumläsionen bzw. revisionspflichtige Einschränkungen der Ureterenfunktion auf. Bluttransfusionen waren nicht erforderlich. Zum Zeitpunkt der Nachuntersuchung (6-8 Wochen postoperativ) stellten sich keine operationswürdigen Rezidive dar, und es musste keine Pessartherapie verordnet werden. Mittelfristige Daten zu Prolapsrezidiven müssen aber abgewartet werden, um eine abschließende Bewertung zu ermöglichen. Die geringe Invasivität, standardisierte anatomische Leitstrukturen, minimaler Materialaufwand und Erhalt der physiologischen Scheidenachse werden von den Autoren als entscheidende Vorteile gegenüber anderen Methoden angesehen. Aufgrund dieser Erfahrungen wird an der Klinik für Urogynäkologie die sakrospinale Fixation nach Amreich und Richter im Rahmen der Prolaps-Hysterektomie nicht mehr durchgeführt.

Die abdominale (offene bzw. laparoskopische) Prolaps-Hysterektomie scheint im klinischen Alltag einen untergeordneten Stellenwert zu haben, ist im Vergleich zum vaginalen Vorgehen aufwendiger und durch Netzerosionen im Scheidengrund belastet, obwohl die anatomischen Ergebnisse exzellent sind. Die Zervikopexie im Rahmen der suprazervikalen Hysterektomie schließt sich den anatomischen Resultaten der Kolpopexie an, aber auch hier sind Fistelungen über den Zervikalkanal möglich.

\section{Fazit}

\section{$\nabla$}

Die Prolaps-Hysterektomie muss mit einer Scheidenstumpffixation kombiniert werden, wenn sie einen Teil der Prolapsrekonstruktion darstellen soll. Aktuell lassen sich grundsätzlich 3 Vorgehensweisen unterscheiden: der vaginale Zugang unter Einbeziehung des gekürzten Halteapparats des Uterus, der zusätzlich vaginale Zugang mit Fixation am Lig. sacrospinale und die Zerviko-/Kolposakropexie mittels Netzinterposition im Rahmen der abdominalen oder laparoskopischen totalen bzw. suprazervikalen Hysterektomie. Alle 3 Vorgehensweisen stellen neben der eigentlichen Hysterektomie eine eigenständige Prozedur dar. Sie bedürfen einer unabhängigen Risikobewertung und sollten somit auch Gegenstand des präoperativen Aufklärungsgesprächs sein. Dies wiederum rechtfertigt die eigenständige Bewertung im DRG-System. Empfehlungen der Fachgesellschaft könnten hier zum einheitlichen Vorgehen beitragen. Die an der Klinik für Urogynäkologie durchgeführte und hier vorgestellte Fixationstechnik bietet ggf. eine gute Diskussionsgrundlage.

\section{Interessenkonflikt}

$\nabla$

Nein.

\section{Conflict of Interest}

$\nabla$

None. 


\section{References}

1 Corman M. Classic articles in colonic and rectal surgery. Alexis Victor Moschcowitz, 1865-1937. The pathogenesis, anatomy, and cure of prolapse of the rectum. Dis Colon Rectum 1983; 26: 553-565

2 Moschcowitz AV. The pathogenesis, anatomy, and cure of prolapse of the rectum. Surg Gynecol Obstet 1912; 15: 7-12

3 Halban J. Gynäkologische Operationslehre. 1. Aufl. Berlin, Wien: Urban \& Schwarzenberg; 1932: 170-173

4 McCall ML. Posterior culdeplasty. Obstet Gynecol 1957; 10: 595-602

5 Aronson MP, Aronson PK, Howard AE et al. Low risk of ureteral obstruction with "deep" (dorsal/posterior) uterosacral ligament suture placement for transvaginal apical suspension. Am J Obstet Gynecol 2005; 192: 1530-1506

6 Cruikshank SH, Kovac SR. Randomized comparison of three surgical methods used at the time of vaginal hysterectomy to prevent posterior enterocele. Am J Obstet Gynecol 1999; 180: 859-865

7 Neeser E, Keller E, Hirsch HA. Prophylaxe des Scheidenvorfalls bei der Hysterektomie durch Suspension des Vaginalstumpfes. Geburtsh Frauenheilk 1990; 50: 789-793

8 Colombo M, Milani R. Sacrospinous ligament fixation and modified McCall culdoplasty during vaginal hysterectomy for advanced uterovaginal prolapse. Am J Obstet Gynecol 1998; 179: 13-20

9 Chene G, Tardieu AS, Savary D et al. Anatomical and functional results of McCall culdoplasty in the prevention of enteroceles and vaginal vault prolapse after vaginal hysterectomy. Int Urogynecol J 2008; 19 : 1007-1011
10 Montella JM, Morrill MY. Effectiveness of the McCall culdeplasty in maintaining support after vaginal hysterectomy. Int Urogynecol J 2005; 16: 226-229

11 Shull BL, Bachofen C, Coates KW et al. A transvaginal approach to repair of apical and other associated sites of pelvic organ prolapse with uterosacral ligaments. Am J Obstet Gynecol 2000; 183: 1365-1374

12 Richter K. Die chirurgische Anatomie der Vaginaefixatio sacrospinalis vaginalis. Ein Beitrag zur operativen Behandlung des Scheidenblindsackprolapses. Geburtsh Frauenheilk 1968; 28: 321-327

13 Maher CF, Cary MP, Slack MC et al. Uterine preservation or hysterectomy at sacrospinous colpopexy for uterovaginal prolapse? Int Urogynecol J 2001; 12: 381-385

14 Lopes ED, Lemos NL, Carramão Sda S et al. Transvaginal polypropylene mesh versus sacrospinous ligament fixation for the treatment of uterine prolapse: 1-year follow-up of a randomized controlled trial. Int Urogynecol J 2010; 21: 389-294

15 Bensinger G, Lind L, Lesser $M$ et al. Abdominal sacral suspensions: analysis of complications using permanent mesh. Am J Obstet Gynecol 2005; 193: 2094-2098

16 Tunn R, DeLancey JO, Quint EE. Visibility of pelvic organ support system structures in magnetic resonance images without an endovaginal coil. Am J Obstet Gynecol 2001; 184: 1156-1163

17 DeLancey JO. Anatomic aspects of vaginal eversion after hysterectomy. Am J Obstet Gynecol 1992; 166: 1717-1724

18 Jacquetin B, Fatton B, Rosenthal C et al. Total transvaginal mesh (TVM) technique for treatment of pelvic organ prolapse: a 3-year prospective follow-up study. Int Urogynecol J 2010; 21: 1455-1462 